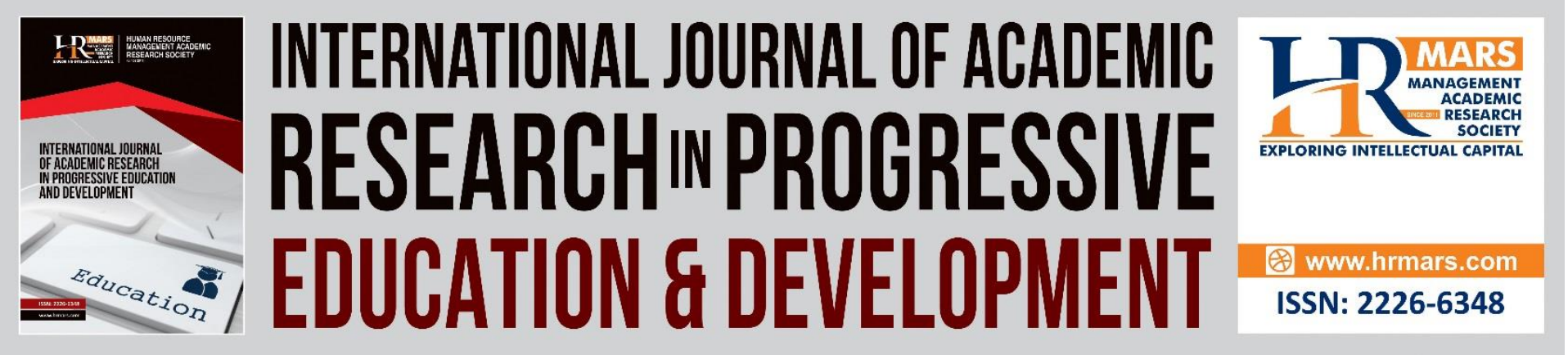

\title{
Perception of Students and Staff on Determinants of Performance in Science Laboratory Technology in Institutes of Technology in Southern Nyanza Region, Kenya
}

\author{
Ojera, Dorcas Akinyi, E. M. W. Simatwa, T. M. O. Ayodo
}

To Link this Article: http://dx.doi.org/10.6007/IJARPED/v1-i4/11967

DOI: $10.6007 /$ IJARPED/v1-i4/11967

Received: 11 October 2012, Revised: 13 November 2012, Accepted: 29 November 2012

Published Online: 21 December 2012

In-Text Citation: (Ojera et al., 2012)

To Cite this Article: Ojera, D. A., Simatwa, E. M. W., \& Ayodo, T. M. O. (2012). Perception of Students and Staff on Determinants of Performance in Science Laboratory Technology in Institutes of Technology in Southern Nyanza Region, Kenya. International Journal of Academic Research in Progressive Education and Development, 1(4), 47-60.

\section{Copyright: @ 2012 The Author(s)}

Published by Human Resource Management Academic Research Society (www.hrmars.com)

This article is published under the Creative Commons Attribution (CC BY 4.0) license. Anyone may reproduce, distribute, translate and create derivative works of this article (for both commercial and non-commercial purposes), subject to full attribution to the original publication and authors. The full terms of this license may be seen at: http://creativecommons.org/licences/by/4.0/legalcode

\section{Vol. 1(4) 2012, Pg. 47- 60}

Full Terms \& Conditions of access and use can be found at http://hrmars.com/index.php/pages/detail/publication-ethics 


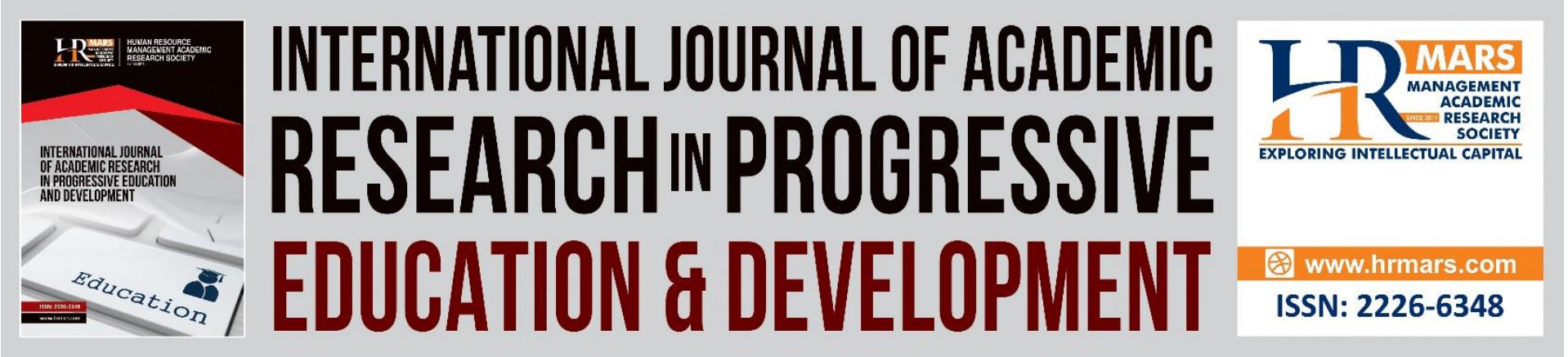

\title{
Perception of Students and Staff on Determinants of Performance in Science Laboratory Technology in Institutes of Technology in Southern Nyanza Region, Kenya
}

\author{
Ojera, Dorcas Akinyi \\ Department of Educational Management and Policy Studies, Moi University, Rongo \\ University College, Kenya \\ Email: dorcasojera@gmail.com \\ Dr. E. M. W. Simatwa, PhD \\ Department of Educational Management and Foundations, University, Maseno, Kenya \\ Prof. T. M. O. Ayodo, PhD \\ Department of Educational Management and Foundations, University, Maseno, Kenya
}

\begin{abstract}
Science Laboratory Technology training is considered pivotal to Kenya's economy, as it is increasingly seen as a vehicle through which the country will build a competitive workforce for key industries within priority sectors identified in Vision 2030. The objective of this article was to find out the contribution of library facilities on performance of students in Science Laboratory Technology in Institutes of Technology in Institutes of Technology in South Nyanza, Kenya. Despite the importance of Science Laboratory Technology, students' performance in Institutes of Technology in South Nyanza, Kenya has been below expectations. For the period between 2006-2010, cumulative performance in Science Laboratory Technology course in Kenya National Examinations has been; Distinction 0 (0\%), Credit 15 (2.63\%); Pass 61 (10.63\%); Referred 219 (38.29\%); and 277 (48.45\%) failed. This dismal performance has led to growing concern among stakeholders. The instruments for data collection were questionnaires, interview schedules, document analysis and observation. A conceptual framework was used to guide the study on factors that determine performance in Science Laboratory Technology. The study adopted descriptive survey design. The study population consisted of 240 students undergoing the Science Laboratory Technology course, 26 lecturers, 3 Librarians and 3 Principals. Simple random sampling technique was used to select 120 students and 18 lecturers while saturated sampling technique was used to select the 3 Principals, 3 librarians and 3 laboratory assistants. It is hoped that this article will provide a basis for future research in the education sector particularly the Institutes of Technology. The Ministry of Higher Education Science and Technology may also use this study
\end{abstract}


to re-evaluate the criteria for student admission into the course Science Laboratory Technology.

Keywords: Student Perception, Determinants, Performance, Science, Laboratory, Institute, Technology

\section{Introduction}

The achievements of a nation are based on advances in science, technology and raising the level of educational achievement in the general population (Hofstain \& Lunetta, 2004). The United Nations recognizes this role and states that the development of effective technical and vocational education systems is at the heart of global education reform efforts (UNESCO, 2004). Chunghwa (2000) in Hong Kong suggested that, from a global perspective, the framework for technological education in any nation must be drawn from a widely recognized, acceptable, national conceptualization of the role of technology in national development.

In the United Kingdom, Tsang (2000) defined vocational training broadly as being any type of job- related learning that raises an individual's productivity. It includes learning that takes place in formal, vocational and technical schools, in training centers or institutes and in work place both on and off-the-job (Oliver et al., 2008). The objective of vocational training is to teach new skills or to upgrade existing skills in order to raise the trainee's capacity to handle the specific job being trained for (Oplatka, 2004). A primary goal of government training is often to meet the required manpower needs to boost economic growth both at grassroots and national level. Hoftain and Lunetta (2004) point out that the inputs to vocational training include the trainees' and the instructors' time, instructional materials, equipment and physical facilities. Chunghwa (2000) states that there are direct and indirect resources devoted to training which constitute the cost of vocational training. Outputs of training include its effects on the trainee and the benefits to the trainee and the society at large. Trainning effect on the trainee includes increment in cognitive and non- cognitive skills that are required in the work place which result in higher earnings (Soto \& Sulekha-Anand, 2009). Training has benefits to the enterprises such as providing lower rate of worker turnover, reduced downtime, reduced input cost and increased worker productivity. The society benefits in increased economic productivity and higher taxable earnings (MacLennan, 2008).Technical and vocational training systems that respond to the needs of the society, industry and individuals are a critical prerequisite to a country's economy (Chunghwa, 2000). Such training should be geared towards education that focuses on skills and technology.

In Kenya, when students join Institutes of Technology, they are expected to pass their national examinations and contribute to nation building, and by extension work towards the achievement of Vision 2030 and the Millennium Development Goals (MDG). Akelo-Misori (2008), suggests that, a clearly defined and articulate technical and vocational training system that responds to the needs of the society, industry and individuals is a pre-requisite for a country to become globally competitive. As a Millennium Development Goal, education that focuses on delivery of skills and technology is a priority sector for the World Bank lending program. In line with these priorities, Kenya in its industrialization strategy of Vision 2030 focuses on technological advancement. Institutes of Technology and vocational training institutions in Kenya are expected to play a leading role in the realization of this vision. One objective of the training is to prepare young people so that they are in a position to cope 
better with their jobs upon leaving school and that they may also gain the skills required to make the most of their work talents (Wolliams, 2006). In Kenya, students enrolled in Institutes of Technology for certificate courses in Science Laboratory Technology are Form four leavers who are required to have attained a minimum grade "D plain" in secondary school, while those who enroll for diploma should have attained ' $\mathrm{C}$-' as minimum grade requirements. The subjects offered in this course are Physics Techniques, Biological Sciences, Laboratory Practical, Chemistry Techniques, and Project Proposal. Other support subjects are Mathematics and Technical Drawing. Successful students find the opportunity to offer essential services to other lab users. In schools they work as Laboratory Assistants, helping students learn without encountering the risks of chemical poisoning or explosions in the laboratory (Hofstain \& Lunetta, 2004). To offer their services, the students must show their competence and qualifications by passing the college exams set by Kenya National Examinations Council (KNEC).

Institutes of Technology are an integral part of Technical Industrial and Vocational Training (TIVET). The improvement in student performance in Science Laboratory Technology course will contribute significantly towards attainment of the country's Industrialization Strategy outlined in Vision 2030. Table 1 shows the performance of students in the various courses offered in Institutes of Technology in the South Nyanza. As can be observed, Science Laboratory Technology is featuring in the last column showing that the performance in this course is poor 
Table 1 Cumulative performance of students in different courses in the last 5 years (2006 2010 in three Institutes of Technology

\begin{tabular}{|c|c|c|c|c|c|c|c|}
\hline Courses & $\begin{array}{l}\text { No. of } \\
\text { students } \\
\text { enrolled }\end{array}$ & $\begin{array}{l}\text { No. of students } \\
\text { with } \\
\text { Distinction }\end{array}$ & Credit & Pass & Referrals & Fail & $\%$ Pass \\
\hline $\begin{array}{l}\text { Textile } \\
\text { technology }\end{array}$ & 300 & 2 & 118 & 170 & 6 & 4 & $96.67 \%$ \\
\hline $\begin{array}{l}\text { Food } \\
\text { \&beverage }\end{array}$ & 364 & 10 & 96 & 220 & 16 & 22 & $89.56 \%$ \\
\hline $\begin{array}{l}\text { Social\& comm. } \\
\text { Dev }\end{array}$ & 400 & 8 & 162 & 150 & 42 & 38 & $80.00 \%$ \\
\hline $\begin{array}{l}\text { Building } \\
\text { construction }\end{array}$ & 180 & - & - & 120 & 40 & 20 & $66.66 \%$ \\
\hline $\begin{array}{l}\text { Welding \& } \quad \& \\
\text { fabrication }\end{array}$ & 220 & - & 40 & 98 & 60 & 22 & $62.72 \%$ \\
\hline $\begin{array}{l}\text { Carpentry \& } \\
\text { joinery }\end{array}$ & 260 & - & - & 160 & 94 & 6 & $61.53 \%$ \\
\hline $\begin{array}{l}\text { Business } \\
\text { studies }\end{array}$ & 597 & - & 106 & 249 & 120 & 122 & $59.46 \%$ \\
\hline $\begin{array}{l}\text { Electrical } \\
\text { engineering }\end{array}$ & 175 & - & - & 98 & 40 & 37 & $56.00 \%$ \\
\hline $\begin{array}{l}\text { Computer } \\
\text { studies }\end{array}$ & 280 & 2 & 24 & 164 & 41 & 49 & $50.00 \%$ \\
\hline $\begin{array}{l}\text { Automotive } \\
\text { engineering }\end{array}$ & 180 & - & - & 97 & 53 & 30 & $49.44 \%$ \\
\hline $\begin{array}{l}\text { Mechanical } \\
\text { engineering }\end{array}$ & 220 & - & - & 89 & 67 & 64 & $40.45 \%$ \\
\hline $\begin{array}{l}\text { Food } \\
\text { technology }\end{array}$ & 230 & - & - & 30 & 180 & 20 & $13.04 \%$ \\
\hline $\begin{array}{l}\text { Science } \\
\text { Laboratory } \\
\text { Technology }\end{array}$ & 572 & - & 4 & 14 & 90 & 464 & $3.15 \%$ \\
\hline TOTAL & 3615 & 22 & 546 & 1649 & 849 & 549 & $61.33 \%$ \\
\hline
\end{tabular}

Source: Moi Institute of Technology, Gusii Institute of Technology and Mawego Institute of Technology. Examinations (KNEC) results for the last five years, from 2006-2010

\section{Statement of the Problem}

Institutes of Technology offer technical as well as business courses at both diploma and certificate levels. In light of Vision 2030, Science Laboratory Technology training is considered pivotal to Kenya's economy, as it is increasingly seen as a vehicle through which the country will build a competitive workforce. In the year 2006 only 8 out of 125 students got a pass grade, while 119 out of 125 failed. In the year 2007 only 10 out of 105 students passed while 95 out of 105 failed. In the year 2008; 14 out of 100 students passed, while 86 out of 100 failed. In the year 2009; 13 out of 112 passed while 99out of 112 failed and in the year 2010, 31 out of 130 students passed and 99 out of 130 students failed (see Table 2). This was of 
great concern to the stake holders. This study hence sought to find out the contribution of library towards student performance in Science Laboratory Technology, South Nyanza, Kenya.

\section{The Concept of Student Performance}

Different writers have defined performance in various ways. Mortimore (2002) defined performance as the achievement under test, while De Jager (2002) defined performance as the change that occurs after an individual has undergone training or planned experience, particularly with regard to individual behavior, knowledge or skill. He also stated that performance relates to student achievement and success in his/her course of study. Okemwa (2000) linked students' performance to effectiveness and described this as the ability of the individual to be productive after formal or vocational training or planned experience. Such effectiveness will be exhibited in individual behavior, knowledge or skill. These definitions depict performance as that which can be observed after training. One important reason behind the selection of this outcome lies in the fact that course grades represent the fulfillment of certain course standards listed in syllabi and known to all enrolled students (Mortimore, 2002). The course standards include various types of assessments such as passing examinations and writing lab reports; therefore, course grades serve as a summative evaluation of student performance (De Jager, 2002). In addition, employers and admissions committees frequently use course grades to gauge student past performance and predict future success. This study reviewed performance in Science Laboratory Technology as affected by the library, the laboratory, lecturer qualification and experience, role of principle's leadership style in provision of learning materials and co-ordination of personnel, and also determined the role of student's entry grade contribution to performance in Science Laboratory Technology. Performance of the student was viewed as the achieved grade in Kenya National Examinations (KNEC) in Science Laboratory Technology course.

\section{Role of the Library Facilities on Performance of Students}

The role of books in complementing and supplementing the teacher's work cannot be overemphasized as textbooks or reading materials stay on as companions long after the student and teachers have parted. In South Africa, Cape Town University, De Jager (2002) reported significant improvement in critical thinking among students who engaged in what was known as independent exploration and focused library activities such as checking citations on reading materials, and borrowing books from the library. He used a large scale survey and document analysis to collect data in the University Library. His respondents were students from both the University's Humanities and Science Departments. His variables of study were achievement of students and borrowing of books. He analyzed his data by comparing results of students from the Faculty of Humanities and the Faculty of Science. He found a positive correlation between undergraduate academic achievement and the use of a variety of library facilities and services. The successful students will have in the past used the library staff for assistance and also used different library materials such as electronic resources, journal articles, books and reference books. He also found that students from Humanities department had a higher ratio of borrowing compared to the science students. Comparing the performance of the two departments, he found that the arts students showed better performance than the science students.

In Kenya, Musakali and Mutula (2007) used their personal experience with the Kenyan higher education system, and literature survey plus observation technique to find out more on the 
adaptation of and integration of the internet as part of the library in Kenyan universities and what the implications were for the said institutions. They surveyed participants in 21 Kenyan Universities on the status of internet provision in Kenya, and internet initiatives and their implications for university libraries. Their findings were that there was clear under-utilization of internet facilities and considerable disparities between and within libraries in levels of general Information Communications Technology (ICT). They concluded that if the use of ICT cannot be widely employed then the benefits resulting from such technologies are likely to be equally curtailed. The study also highlighted that university libraries are heavily laden with outdated collections and subscriptions while new acquisitions are very minimal.

These studies suggest that intensive use of the library facilities is likely to boost student performance; that the library should be updated in subscriptions and book collections and also that the effective application of Information Communications Technology (ICT) in the library will boost performance of students. The two studies focused on universities while largely using literature survey. De Jager (2002) suggested significant areas for future researchers to explore among others, library technological support on student success.

However, none of these studies has based the effect of the library facility on student performance in Science Laboratory Technology or Institute of Technology. While these studies have largely used document analysis and survey in universities, this present study adopted descriptive survey, using questionnaire, interview schedule and document analysis to find out perceptions on how the library can contribute to performance of students studying Science Laboratory Technology in Institutes of Technology in the South Nyanza, Kenya.

\section{Methodology}

The study adopted descriptive survey research design. The purpose of this research design was to obtain pertinent and precise information concerning the current status of phenomenon and whenever possible to draw valid general conclusions from facts discovered. Descriptive survey is the means through which opinion, attitude and suggestions for improvement of educational practices and instructions and other data can be obtained (Gall et al, 2007). In addition, they are of immense value in solving problems in school organization, supervision and administration (Koul, 2004). The descriptive survey research design was suitable for this study because the descriptive study determines and reports the way things are. The researcher adopted this descriptive research design to be able to describe the phenomenon as it is on the ground.

The population of the study consisted of 240 students undergoing the Science Laboratory Technology course; 26 lecturers in SLT department; 3 Librarians; 3 laboratory technicians and the 3 Principals as the chief coordinators of resources. Table 2. shows the sampling frame and sampling technique that was used in the study 
Table 2. Sampling Frame

\begin{tabular}{lllll}
\hline Sampling units & Sampling Technique & Population & Sample size & \% of the sample \\
\hline Students & Simple random & 240 & 120 & $50 \%$ \\
Lecturers & Simple Random & 26 & 18 & $69.23 \%$ \\
Principals & Saturated & 3 & 3 & $100 \%$ \\
Librarians & Saturated & 3 & 3 & $100 \%$ \\
Lab technicians & Saturated & 3 & 3 & $100 \%$ \\
\hline
\end{tabular}

The instruments that were used in this study were; the questionnaires, interview schedule, document review and observation schedule. Questionnaires guarantee confidentiality (Koul, 2004). Interview schedules are flexible and can verify the information in the questionnaire. In-depth interviews are one of the methods used in descriptive designs to act as follow up instrument for gathering more data (Koul, 2004). There was an interview schedule for Principals, a questionnaire for lecturers and a questionnaire for students.

The questionnaire consisted of open ended questions used to collect general information on students. The instrument was preferable because the respondents were literate and could be found in one place. Data collected was both qualitative and quantitative (Gall et al., 2007). Librarian's questionnaire consisted of questions regarding personal information such as educational qualifications, experience and a 5 point likert-scale on the perception about the library. Observation is the systematic viewing coupled with consideration of the phenomena that is seen. The observation process may involve one or more persons observing what is occurring in some real life situation. They classify and record pertinent happenings according to some planned schedules (Koul, 2004). Areas to be observed in this survey were listed and the schedule used by the researcher to collect information as was observed. The researcher sought to observe the laboratory for equipment, reagents and working space, library for book collection, computer and internet connection and library furniture if comfortable (See Appendix F). Documents refer to any kind of information that exists in some type of written or printed form (Mugenda, 2008). In the Institutes of Technology, students' records of entry grades, end-term report cards and final performance in national examinations were considered for analysis. The advantage of using document review is that one is able to obtain unobtrusive information which saves time in transcription. The student's performance records were examined to extract quantitative data. This study examined the documented records of the Kenya National Examination Council (KNEC) final result from the year 2006 to 2010 and the students' entry grades at the time of joining the institution was also analyzed.

Face Validity refers to the extent to which the instrument appears to measure what it is supposed to measure (Gall et al., 2007). Face validity was done by experts in research methodology from the Department of Educational Management and Foundations of Maseno University who reorganized the questions to address the outlined study objectives. Reliability is a measure of the degree to which research instrument yields consistent results or data after repeated trials (Gall et al., 2007). A pilot study using test re-test method was done using $5 \%$ of population not in the study sample. The test- retest was done by exposing the respondents to the questionnaire, then after two weeks exposing them again to the same questionnaire and the responses compared to see if the questions were understood and answered in a consistent manner. Corrections were then made on the instrument so that consistent results 
could be attained (Mugenda, 2008). This was done to clear any vague or ambiguous parts of the questionnaire.

\section{Data Collection Procedures}

Permission was sought from the National Council of Science and Technology through the School of Graduate Studies (S.G.S) and Department of Educational Management and Foundation, Faculty of Education. The Principals of the institutes, the heads of departments concerned and the lecturers were informed and notified two weeks before the date of data collection. The researcher administered the questionnaires to the students, lecturers, librarians and the laboratory assistant. The interview with the principals was administered by the researcher and taped by the researcher.

The questionnaires, document review, interviews schedules and observation schedules yielded both quantitative and qualitative raw data. Quantitative data were analyzed and summarized using descriptive statistics in form of means, percentages and frequencies. Qualitative data were recorded then transcribed and organized into categories as they emerged from the study (Mugenda, 2008).

\section{Results and Discussion}

Contribution of the library facilities on performance of students in Science Laboratory Technology in Institutes of Technology in the South Nyanza, Kenya

The research question responded to was: How do the Library facilities contribute to performance of students in Science Laboratory Technology? The responses have been calculated on a 5 point likert -scale (see appendix $\mathrm{G}$ ) and the results can be seen in Table 4.1. The five point Likert-Scale values were as follows; Strongly Agree $(S A)=5$; Agree $(A)=4$; Undecided (UD) =3; Disagree (D)= 2; Strongly Disagree (SD) =1.

Table 4.1 Shows that adequate borrowing period of books was rated highly 4.83 by students; 4,33 by lecturers and 4.00 by librarians. The adequate period enables the students to use the books optimally. This enhances their understanding of the subject matter and therefore performance in Science Laboratory Technology course. This finding is consistent with De Jager (2002) who found that the use of the library facilities by students makes them improve their critical thinking long after the students have parted with their teacher. This finding concurred with the views of the principals that, "if students use the library effectively, they improve on their performance" 
Table 4.1: Contribution of library based factors on students' performance in Science Laboratory Technology as rated by; Students $(n=120)$; Lecturers $(n=18)$; and Librarians $(n=3)$

\section{LIBRARY BASED FACTORS STUDENTS' LECTURERS' LIBRARIANS'Me Mean Rating Mean Rating an Rating}

\begin{tabular}{|c|c|c|c|}
\hline Adequate period of borrowing books & 4.83 & 4.33 & 4.00 \\
\hline $\begin{array}{l}\text { Good Terms of borrowing and returning } \\
\text { reading materials }\end{array}$ & 4.83 & 4.11 & 4.00 \\
\hline Adequate reading space for all students & 3.67 & 3.22 & 4.00 \\
\hline There is security at night for library users & 3.50 & 3,22 & 4.00 \\
\hline Good lighting in library & 3.50 & 3.06 & 3.33 \\
\hline $\begin{array}{l}\text { Conducive reading environment in the } \\
\text { library }\end{array}$ & 3.42 & 3.22 & 3.33 \\
\hline Efficient staff & 3.33 & 3.89 & 5.00 \\
\hline $\begin{array}{l}\text { Well stocked short loan section with SLT } \\
\text { books }\end{array}$ & 2.25 & 2.00 & 2.67 \\
\hline Photocopy facility available & 1.83 & 1.56 & 1.67 \\
\hline
\end{tabular}

Table 4.1 shows that good terms of borrowing and returning the reading material was rated 4.83 by students, 4.11 by lecturers and 4.00 by librarians. During interviews one of the principals emphasized that students must have library cards and students identification documents in order to borrow any material from the library. This condition makes it possible for all the genuine students pursuing their studies seriously to access the required materials, and use them effectively. Other conditions like replacing lost items by students who lose them guarantee the next user get same reference materials. Fining for those who delay to return the items on time forces the borrower to make full use of items borrowed before time expires and also guarantees the next user gets the materials for optimum use. The optimum use of library materials help the students to perform better. This finding agrees with the finding of Musakali and Mutula (2007) who found out that the use of the library materials help students to perform better.

Adequate reading space in the library was rated 3.67 by the students; 3.22 by the lecturers and 4.00 by the librarian. The adequate reading space helps the students to read in the library without feeling squeezed and suffocated which will allow free circulation of air helps in allowing optimum performance by the students. Uline and Moran (2006) in their research; walls speak, the interplay of quality facilities, school climate and student achievement found that air temperature and quality in a building affect students performance. In rooms with no proper ventilation the students' achievement is impaired.

Security here refers to how safe do students feel when going to the library in the night. If the library is safe and they can also walk safely back to hostel. During observation it was noted that there is no lighting in the walk-ways towards the library. This means the paths are dark after sunset. The students rated security 3.50; the lecturers 3.22 and the librarians 4.00 . This 
means that the students and the lecturers are not sure of the security and so the students may avoid going to the library at night and so waste valuable study time.

Lighting in the library was rated 3.50 by the students; 3.06 by the lecturers and 3.33 by the librarians. From observation it was noted that the lighting bulbs were placed far apart and this formed shadows which discouraged serious studies. From observation of one of the libraries the researcher found that there were no lighting fixtures in the library making it impossible to study in the library at night. The ratings show that the lighting in the library was not very effective or bright enough to encourage serious study.

Conducive reading environment in the library means the library is quiet enough and has comfortable reading furniture this was rated 3.42 by the students; 3.22 by the lecturers and 3.33 by the librarians. From observation, it was noted that one of the libraries had benches with no back rest and communal tables for the students do their studies. These facilities make the library user dissatisfied. Library staff efficiency means the staff is ready to assist the students locate books this was rated 3.33 by the students, 3,89 by the lecturers and 5.00 by the librarians This shows the staff are not very helpful to students in locating books and other materials..

The question on whether Short loan section of the library was well stocked with science Laboratory text books was rated 2.25 by students; 2.00 by lecturers and 2.267 by librarian. This shows that the libraries lack most books on SLT even on short loan. This makes the user dissatisfied with the library facility as was also found out by De jager (2002) that student satisfaction with the library was as a result of being able to find material and lack of materials make them dissatisfied with the library. This lack of reading material will contribute to student performance negatively. Availability of photocopy facility was rated 1.83 by the students; 1.56 by the lecturers and 1.67 by the librarian. From observation it was noted that there was no photocopier in the library. Photocopiers make it easy for lecturers to make hand-out for students. The students may also make copies of relevant pages from periodicals or books.

The results indicated on Table 4.1 show that there are no photocopy facilities, computers and internet connection in the libraries. These results also indicate that the students do not make full use of the library due to the setback they experience in the poor or no lighting at night and also due to the uncomfortable furniture. The library facilities are inadequate in supply of reading materials and there were no computers to make use internet reading materials a likely indication of poor learning conditions. This indicates that the students do not optimize their study hours due to non conducive study library environment which contributes negatively to students academic performance.

\section{Conclusion}

This study made the following conclusion based on the findings:

The study revealed that the libraries at the institutes of technology have very few text books related to SLT and other reference materials for Science Laboratory Technology. Records keeping in the libraries were manual due to lack of computers and at times it was rather difficult to locate the few books due to poor book arrangement. Due to insufficient relevant text books, the students are left to rely mostly on the teachers' notes. 
DEVELOPMENT

Vol. 1, No. 4, 2012, E-ISSN: $2226-6348$ @ 2012 HRMARS

\section{Recommendation}

Based on the findings that the libraries of the institutes of technology had insufficient books, used manual cataloging systems, not connected to internet, had small space which take few students at a time; the study concludes that libraries in Institutes of Technology to some extent do not provide adequate library services that could enhance performance. This implies that the poor performance recorded may be due to poor library conditions. This study recommends that for a library to be active, current books or periodicals should be provided and for the students to use the library effectively, computers should be provided to make it possible to access the internet while in the library. It futher recommended that The Ministry of Higher Education Science and Technology should provide funds to help put up modern libraries with computers so that students can access the internet and make use of online information that cannot be found in the books. Effort should be made to provide books for Science Laboratory Technology in the library. The institutes should provide better furniture into the libraries to encourage students to visit and study in the library. The students and the lecturers recommended that the following be added to the library Text books relevant to SLT; computers and Internet facilities; better lighting and better furniture.

\section{References}

Ainley, J. (2000). Students views on their schools. Psychological Bulletin. 21, 5-16

Akelo-Misori, M. T. (2008). Higher education is ripe for reform. The Standard Newspaper, p.6, Nairobi, Kenya.

Akanle, O. B. (2007). Socio-Economic Factors Influencing Students Academic Performance in Nigeria; Some Explanation from a Local Survey. Journal of Personality and Social Psychology.32,28-30.

Chunghwa, W. B. (2000). Technology Education and World Development: Challenges and Opportunities for Education in Africa. The Journal of Educational Administration 16,4046.

Cohen, L., \& Manon, L. (1997).Research methods in education, 4th edition, Guidford Melbourn publishers.

Cybusky, W., Wayne, A. J., \& Sweetland, D. (2004). The role of collective efficacy of teachers, and fiscal efficiency in student achievement. Journal of Educational Administration.5, 439-461.

Danesty, A. H. (2004). Psychosocial determinants of academic performance and vocational learning of students with disabilities in Oyo State. Unpublished Doctor of philosophyThesis, University of Ibadan, Nigeria.

Darling-Hammond, L., \& Berry, B. (2000). Recruiting teachers for the $21^{\text {st }}$ century: The foundations for educational equity. Journal of Negro Education.3, 254-279.

De Jager, K. (2002). Successful students; Does the library make a deference in the performance measurements and merits? Journal of Educational Administration.3,140144

Drennan, L., \& Beck, M. (2001).Teaching quality performance indicators:key influences on the UK universities' scores. Journal of Quality Assurance in Education, 9, 92-102.

Fraenkline, W. (2004). Principals and students perceptions on school resouce management Journal of Educational Management.6,47-59.

Freeman, S., O'Connor, E., Parks, J. W., Cunningham, M., Hurley, D., Haak, D., Dirks, C. \& Wenderoth, M. P. (2007). Prescribed Active Learning Increases Performance in Introductory Biology. Journal of life esciences: Cell Biology. 6, 132-139. 
Gall, M. D., Gall, J. P., \& Borg, W. R. (2007). EducationalRresearch; An introduction. 8th Edition. New York, U.S.A. Zondervan publishers.

Gay, L. R. (2000). Educational research: Competencies for analysis and application. 3rd Edition, Kingsway publications.

Griffith, J., (2004). Relation of principal transformational leadership to school staff job Satisfaction, staff turnover and school performance. Journal of Educational Administration. 42, 194-254.

Goldring, E., Huff, J., May, H., \& Camburn, E. (2008). School context and individual Characteristics: What influences principal practice? Journal of Educational Administration. 46,(3). 332-352.

Hofstein, A., \& Lunetta, V. N. (2004). The laboratory in science education; foundations for the $21^{\text {st }}$ century. Scientific reports Journal 45(4).23-34. Department of science technology, Institute of Science Education, Israel.

Koul, L. (2004). Methodology of educational research; $3^{\text {rd }}$ edition. New Delhi, Wishwa Prakashan publications.

Leithwood, K., \& Jantzi, D. (2000). The effects of transformational leadership on organizational Conditions: Student's engagement with school. Journal of Educational Administration 13, (5) 231-264.

Linn, C. M. (2007). The role of laboratory in science learning, Special issue. Elementary School Journal. 97, (4). 401- 417.

MacLennan, A. (2008). Research in Technical Training Colleges. Journal of Education and Training 50, (1) 33-39

Mercer, J. (2005). Challenging appraisal orthodoxies; Teacher evaluation and professional development in United Arab Emirates. Journal of Personal Evaluation in Education 2 (1) 19-42.

Mortimore, P. (2002), "High performing schools and school improvement".Journal of Educational Administration 53,(6).47-49.

Mugenda, A. G. (2008). Social ScienceRresearch: Theory and principles. Applied research and training. Nairobi, Kenya. Services publishers

Musakali, O. D., \& Mutula, M. S. (2007). Internet adoption and assimilation in Kenya Universities libraries. Library review, Journal of Educational Management 56(6).464475.

Ngware, M. W., Wamukuru, D. K., \& Odebero, S. O. (2006). Total quality management in secondary schools in Kenya; Extent and practice. Journal of Educational Management $14,(4), 39-36$

Odhiambo, G. (2008). Elusive search for quality education: The case of quality assurance and teacher accountability. International Journal of Educational Management, 22(7)34-254

Okemwa, E. (2000). Training needs of practicing professional librarians in the Kenyan public university libraries: A critical analysis..Journal of Library Management. 21.(5). 257-268

Oliver, R. H., Kersten, H., Vinkka-Puhakka, G., Alpasan, D., Bearn,I., Cema, E., Delap, P., Dummer, J. P., Goulet, T., Gugushe, E., Jeniati,V., Jerolimov, N., Kotsanos, S., Krifka, G., Levy, M., Neway, T., Ogawa,M., Saag, A., Sidlauskas, U., Skaleric, M. Vervoorn, Y. \& White, D. (2008). Curriculum structure: principles and strategy, $S$ 2.1, Journal compilation, Blackwell Munksgaard and The American Dental Education Association, European Journal of Dental Education ISSN 1396-5883 (Suppl. 1), 74-84

Oplatka, I. (2004). Principalship in developing countries; Context, characteristics and reality Journal of Comparative Education, 40(3).423-456 
Quinn, D. M. (2002). The impact of principal leadership behavior on instructional practice and student engagement. Journal of Educational Administration. 40,( 5).447-467.

Reynolds, W. S. (2000). An analysis of factors that influence student performance; a fresh approach to an old debate. Journal of educational management. 43,(2) 134-415.

Sadler, P. M., \& Tai, R. H. (2001). Success in introductory college physics: The role of high school preparation. Journal of Science Education 85, 111-136.

Schneider, M. (2003), "Linking school facility conditions to teacher satisfaction and success", National Clearinghouse for Educational Facilities available at < www.edfacilities,org/pubs/teachersurvey.pdf.(a)gmail.com> accessed on 30/10/2011 9;30am

Singer, S. R., Hilton, M. L., \& Schweingruber, H. A. (2005). America's lab report: Investigations on high school science. Committee report on High School Science Laboratories; Role and Vision, National Research Council.

Soto, J. G., \& Sulekha-Anand, S. (2009). Factors influencing academic performance of Students enrolled in a lower division Cell Biology core course. Journal of the Scholarship, Teaching and Learning, 9, (1),. $64-80$.

Tsang, M. C. (2000). "Cost analysis and educational policy making; A review of cost studies in Education in developing countries. Review of Educational Research. 58, 181-30

UNESCO. (2004). Developing Technical and Vocational Education in Sub - Saharan Africa.

Wanzare, Z., \& Ward, K. L. (2002) Rethinking Staff development in Kenya. Agenda for the $21^{\text {St }}$ Centaury, International Journal of Educational Management 14(6), $265-275$.

Wayne, J., \& Young, P. (2003). Teacher characteristics and student achievement. Journal of Educational Research 73. (2). 89-122.

Wolliams, J., Lloyd, M., \& Spenger, J. D. (2006). The case for sustainable laboratories: First steps at Harvard university. International Journal of Sustainability in Higher Education 6 (4) 363-382.

Woobman, L. (2003). Schooling resource; Educational institutions and student performance the International evidence. Backwell Educational publishers. Institute of economic Research, Munich, Germany. 